\section{UNIVERSITAS MUHAMMADIYAH MALANG} JP2SD (JURNAL PEMIKIRAN

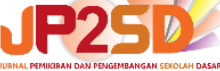

\title{
Persepsi Mahasiswa dalam Penggunaan Ragam Platform Pembelajaran Daring
}

\author{
Sucahyo Mas'an Al Wahid ${ }^{a 1}$, Frendy Aru Fantiro ${ }^{\text {b2 }}$, Dedi Kusnadi ${ }^{\text {3 }}$ \\ aniversitas Borneo Tarakan, Indonesia \\ bUniversitas Muhammadiyah Malang, Indonesia \\ 1 cahyowahid@gmail.com, ${ }^{2}$ frendy_aru@umm.ac.id, ${ }^{3}$ dedikusnadi4289@gmail.com
}

\begin{tabular}{ll}
\hline \multicolumn{2}{l}{ INFORMASI ARTIKEL } \\
\hline Riwayat: & \\
Diterima & 18 Agustus \\
& 2020 \\
Revisi & 13 September \\
& 2020 \\
Dipublikasikan & 26 September \\
& 2020
\end{tabular}

\section{Kata kunci:}

persepsi, platform, pembelajaran daring, mahasiswa PGSD

\section{ABSTRAK}

Koneksi internet dan jaringan menjadi kebutuhan pada era globalisasi saat ini, apalagi dihadapkan situasi permasalahan pada kondisi covid-19. Bukan hanya perekonomian yang berdampak seperti pada pemberitaan yang ada, akan tetapi sistem pembelajaran pun ikut beradaptasi. Seperti sistem perkuliahan mode daring yang dapat mengoptimalkan interaksi antara dosen dan mahasiswa melalui forum diskusi yang terdapat pada platform yang digunakan. Tujuan penelitian mengenal persepsi mahasiswa dalam pemanfaatan berbagai macam moda platform pembelajaran daring. Jenis penelitian survey berupa angket, uji validitas oleh ahli bahasa dan ahli konten platform yang pernah terlibat melaksanakan pembelajaran daring, kemudian dilakukan paparan analisis secara deskriptif. Hasil analisis menunjukkan bahwa, kesiapan pengisian angket oleh mahasiswa 45 dari 100 , presentasi pengetahuan tentang platform $95 \%$ menguasai secara otodidak. persepsi terkait platform chatting room familiar namun kurang dalam keefektifan pemberian materi, persepsi terhadap platform virtual class fitur sesuai tetapi berbasis sinkronus, persepsi pemberian platform video conference kelayakan pembelajaran daring memuaskan jika jaringan stabil.

\section{ABSTRACT}

Internet and network connections are a necessity in the current era of globalization, especially when faced with a problematic situation in the Covid-19 conditions. It is not only the economy that has an impact like the existing news, but the learning system also adapts. Such as an online mode lecture system that can optimize interactions between lecturers and students through discussion forums on the platform used. The research objective is to identify students' perceptions in the use of various modes of online 
Copyright (C) 2020, Sucahyo Mas'an Al Wahid, Frendy Aru Fantiro, Dedi Kusnadi

This is an open access article under the CC-BY-SA license learning platforms. This type of survey research is in the form of a questionnaire, validity testing by linguists and platform content experts who have been involved in implementing online learning, then a descriptive analysis is carried out. The results of the analysis show that, the readiness of filling out the questionnaire by students is 45 out of 100, the presentation of knowledge about the platform is $95 \%$ self-taught. perceptions related to chat room platforms are familiar but lacking in the effectiveness of providing material, perceptions of virtual class platform features are appropriate but synchronous based, perceptions of providing a video conference platform on the feasibility of online learning are satisfactory if the network is stable.

How to cite: Sucahyo Mas'an Al Wahid, Frendy Aru Fantiro, Dedi Kusnadi. (2020). Persepsi Mahasiswa dalam Penggunaan Ragam Platform Pembelajaran Daring. Jurnal Pemikiran dan Pengembangan Sekolah Dasar, Vol 8 No 2, 170-178. doi: 10.22219/jp2sd.v8i2.15030

\section{PENDAHULUAN}

Koneksi internet dan jaringan menjadi hal yang sangat dibutuhkan pada era globalisasi saat ini, apalagi dihadapkan oleh situasi permasalahan pada kondisi pandemik Covid-19. Bukan hanya perekonomian saja yang berdampak seperti pada pemberitaan yang ada saat ini, akan tetapi sistem pembelajaran pun ikut beradaptasi. Seperti sistem perkuliahan mode daring yang dapat mengoptimalkan interaksi antara dosen dan mahasiswa melalui forum diskusi yang terdapat pada platform yang digunakan. Sistem pembelajaran dengan mengintegrasikan koneksi internet dengan proses belajar mengajar dikenal sistem online learning atau sistem belajar virtual (Bentley et all, 2012). Online learning masih dianggap sebagai terobosan belajar mengajar atau paradigma baru bagi sebagian mahasiswa pada kondisi yang terjadi saat ini, sehingga menjadi pemanfaatan dalam kegiatan belajar mengajar yang telah terjadwal dan harus dilaksanakan..

Pembelajaran daring bukan suatu jenis pembelajaran yang tanpa permasalahan dalam prosesnya. Ada beberapa permasalahan yang muncul dalam pembelajaran online seperti yang dikatakan oleh Fortune dan robert 3 hal permasalahan yang biasa muncul pada pembelajaran online yaitu penggunaan materi ajar, interaksi mahasiswa dan suasana belajar. Diperkuat juga oleh hasil survei pada mahasiswa UBT matakuliah PSEBKP terdapat $52,9 \%$ mahasiswa memilih hadir dikelas sedangkan yang menginginkan pembelajaran daring hanya $8,8 \%$ selebihnya tidak tahu.

Penelitian ini bertujuan untuk mengetahui persepsi mahasiswa terhadap keinginan dosen dalam penggunaan berbagai macam pada platform chatting room, tanya jawab, virtual class, video conference pembelajaran daring Mahasiswa Universitas Borneo Tarakan khususnya mahasiswa Pendidikan Guru Sekolah Dasar serta kendala yang dihadapi dalam beradaptasi pada beberapa paltform yang digunakan dalam proses pembelajaran. Manfaat penelitian yaitu efektivitas dan rujukan dalam penggunaan berbagai macam platform pada pembelajaran daring yang disajikan berupa gambar dan tabel. Hasil penelitian yang relevan terdapat pada Saifuddin (108:2020) terkait persepsi yang baik terhadap daring berdasarkan pengetahuan dan pengalaman mahasiswa sehingga memperoleh angka sebesar $86,3 \%$ untuk pembelajaran daring dan fokus pada platform virtual class e-learning Universitas Ahmad Dahlan. 


\section{METODE}

Jenis penelitian survey yaitu peneliti mengumpulkan data secara kuantitatif berupa angket, quisonaire, interview dan data yang dapat dianalisis secara statistik untuk menunjukkan tren dari respon yang diberikan oleh populasi sasaran tentang fenomena yang di bahas (Creswell:2012). teknik pengumpulan data yang dipilih peneliti berupa angket, dengan sampel mahasiswa yang dipilih sebanyak 100 mahasiswa terdiri dari angkatan 2017, 2018 dan 2019. tahapan yang dilakukan berupa:

\section{Persiapan}

Pembuatan dan penyusunan instrument angket berupa pernyataan dan pertanyaan essay yang digunakan untuk pengumpulan data. Informasi yang termuat yaitu: kesiapan pembelajaran daring, manajemen daring, penggunaan platform, saran perbaikan pembelajaran daring.

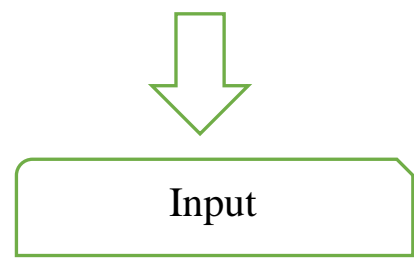

Angket yang telah tersusun kemudian di uji validitas oleh ahli bahasa dan ahli konten platform yang pernah terlibat melaksanakan pembelajaran daring.

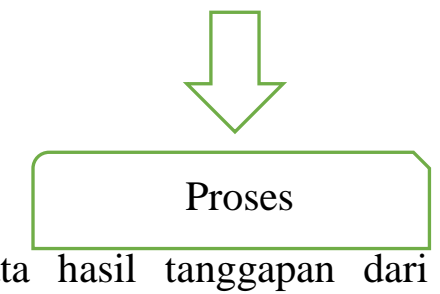

Mengumpulkan data hasil tanggapan dari mahasiswa yang telah bersedia meluangkan waktu dan berpartisipasi memberikan paket data dalam mengisi angket.

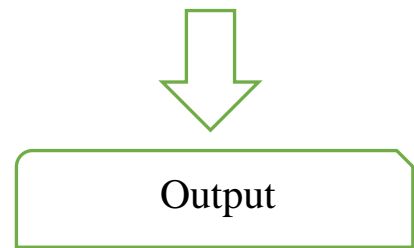

Data yang telah diperoleh berupa data kualitatif dan kuantitatif, yang kemudian dilakukan paparan analisis secara deskriptif.

\section{HASIL DAN PEMBAHASAN}

Kesiapan dalam pengisian angket juga dapat dipertimbangkan terkait mahasiswa menggunakan paket dalam pengisian dan biaya sendiri. Dapat diberikan gambaran beberapa mahasiswa siap dan bersedia mengisi angket platform dalam pembelajaran daring yang diberikan oleh peneliti. 


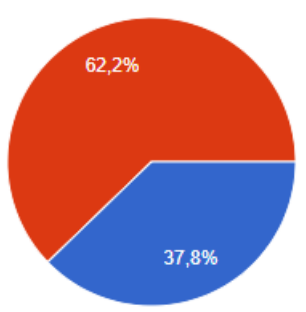

\section{Gambar 1. Kesiapan Pengisian Angket}

Perolehan data setelah diberikan angket pada mahasiswa tidak sesuai ekspetasi peneliti yang berjumlah 100 mahasiswa tetapi terkonfirmasi mengisi hanya 45 mahasiswa, yang terdiri dari angkatan 2017 sebanyak 10 angket yang terisi dari jumlah keseluruhan 64 mahasiswa atau persentase sebesar 15\%. mahasiswa angkatan 2018 yang bersedia mengisi angket sejumlah 15 mahasiswa dari total keseluruhan 75 dengan presentase sebesar $20 \%$ mahasiswa, serta angkatan 2019 yang mampu mengisi angket sejumlah 20 mahasiswa dari total keseluruhan 97 mahasiswa yaitu presentase sebesar $21 \%$. bahwa hasil respon dapat memberikan tanggapan yang bisa dijadikan data penelitian karena memiliki presentase di atas $50 \%$.

\begin{tabular}{cccc}
\multicolumn{4}{c}{ Tabel 1 presentase pengisian angket } \\
\hline $\begin{array}{c}\text { Angk } \\
\text { t. }\end{array}$ & $\begin{array}{c}\text { Jumlah } \\
\text { mahasiswa }\end{array}$ & $\begin{array}{c}\text { Angke } \\
\text { t terisi }\end{array}$ & persentase \\
\hline 2017 & 64 & 10 & $15 \%$ \\
2018 & 75 & 15 & $20 \%$ \\
2019 & 97 & 20 & $21 \%$ \\
\hline
\end{tabular}

Data yang diperoleh melalui angket berupa respon penggunaan platform daring. Dipresentasikan berdasarkan aspek yang dilaksanakan serta paparan deskripsi kualitatif berdasarkan respon yang disampaikan.

platform apa yang pernah anda ketahui?

43 tanggapan

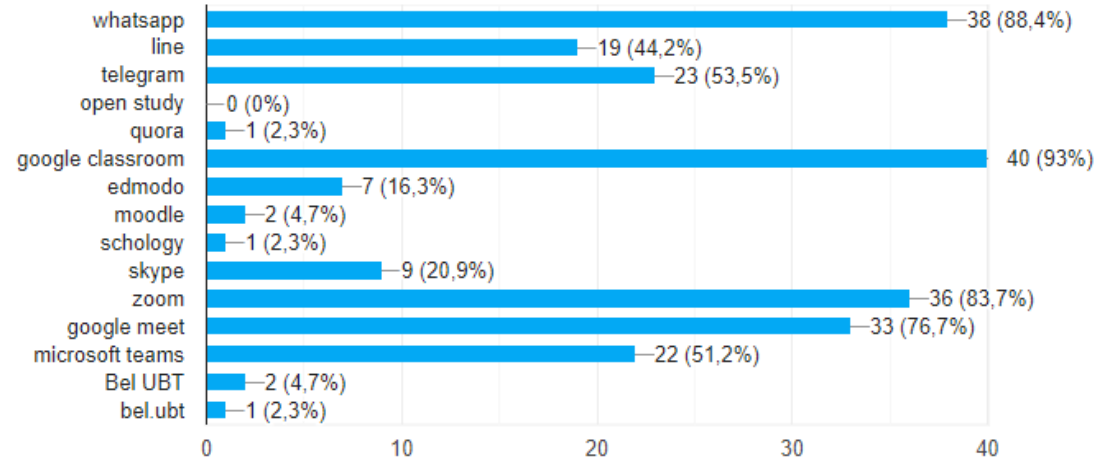

Gambar 2. Analisis Pengetahuan Platform 
Berdasarkan data angket wawancara diperoleh informasi pengetahuan platform yang pernah diketahui dan digunakan pada mahasiswa PGSD FKIP UBT pada Semester Genap 2019/2020 dengan total 14 platform oleh 43 mahasiswa dan rata-rata mahasiswa mengetahui lebih dari 1 platform yang terdiri dari pengguna whatsapp dalam pembelajaran daring $88,4 \%$, pengguna line $44,2 \%$, telegram $53,5 \%$, open study $0 \%$, quora $2,3 \%$, classroom $93 \%$, edmodo $16,3 \%$, moodle $4,7 \%$, schology $2,3 \%$, skype $20,9 \%$, zoom $83,7 \%$, google meet $76,7 \%$, teams 51,2\%, BEL UBT 5\%. berbeda dengan pengetahuan mahasiswa terkait platform oleh Suci Ferdiana (2020) yang menyatakan bahwa pemahaman awal pembelajaran online mahasiswa pada aplikasi zoom 53,4\%, whats up 41,7\%, google classroom 8,7\%, youtube 15,6\%, moodle 12, $6 \%$ dan quizezz $2 \%$.

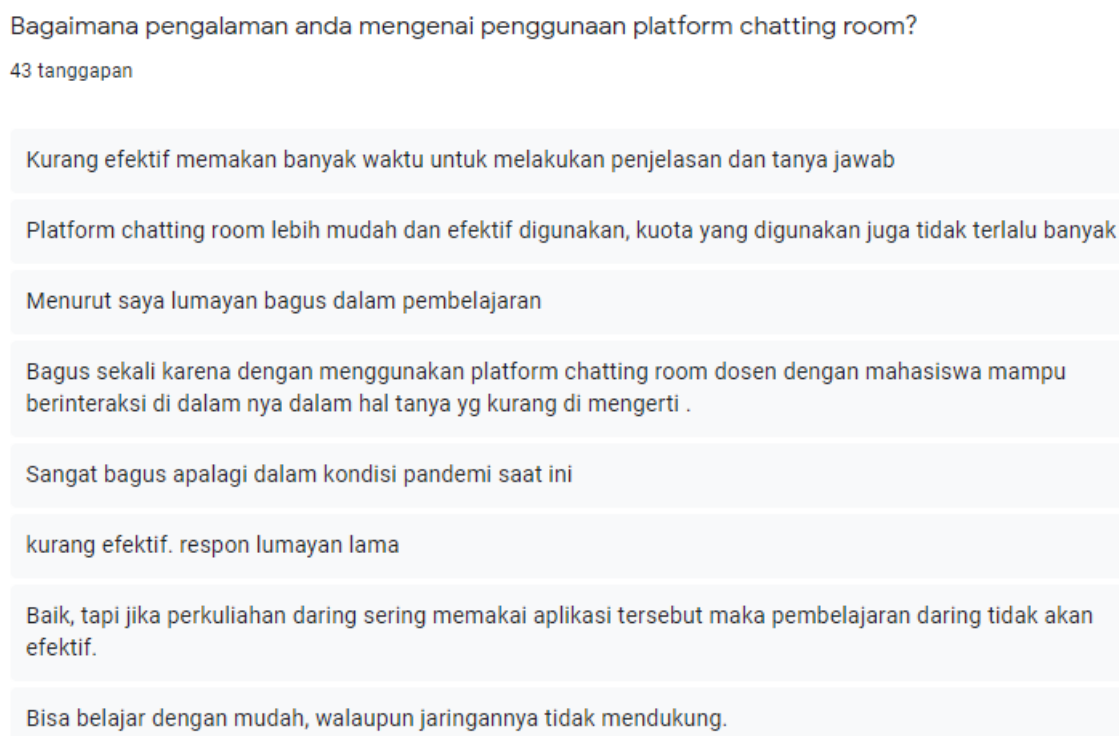

Gambar 3. Persepsi platform chatting room

Pembelajaran daring menggunakan platform chatting room mudah dalam pengaplikasiannya namun sering terjadi perbedaan pandangan terkait materi yang dipaparkan baik melalui video pembelajaran ataupun chatting khususnya penugasan. Sesuai berdasarkan pernyataan Zhafira (2020) peminatan pola komunikasi dua arah whats up yang diminati sebanyak $53 \%$.

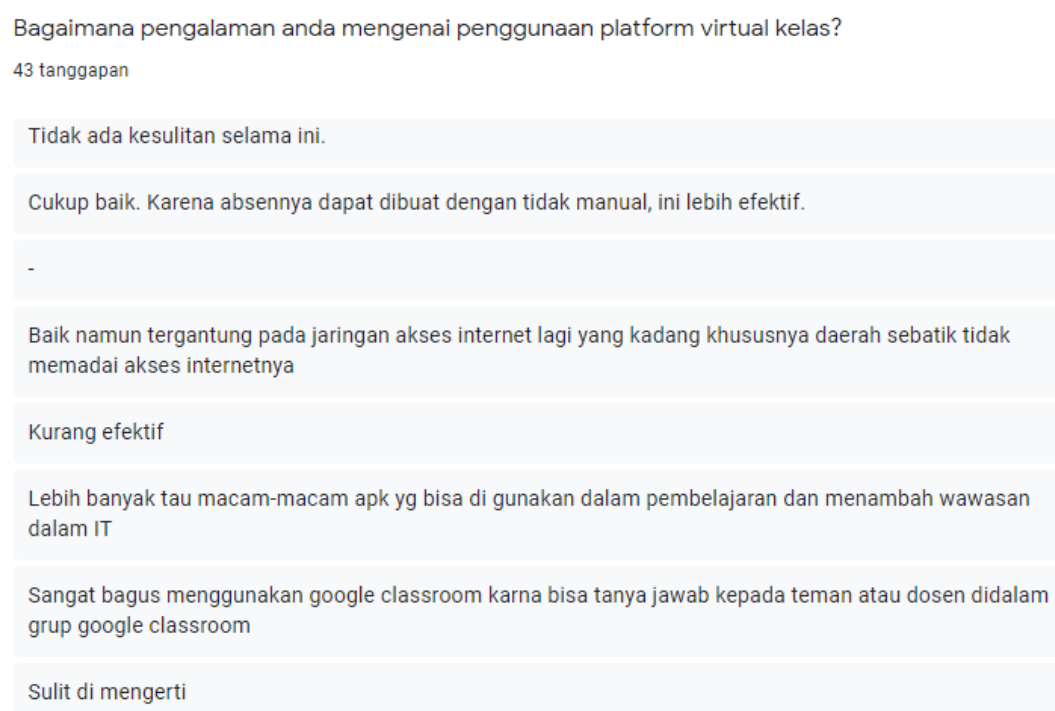

Gambar 4. Persepsi platform virtual class 
Pembelajaran daring menggunakan platform virtual class, fitur yang diberikan tepat untuk pembelajaran sinkronus. sejalan dengan pendapat Alfina (2020) selain efektif juga menjadi pengalaman baru bagi mahasiswa dalam memahami fitur khususnya pada platform google classroom. Selain itu juga menambah wawasan dalam kesiapan menghadapi pembelajaran pada abad ke 21 .

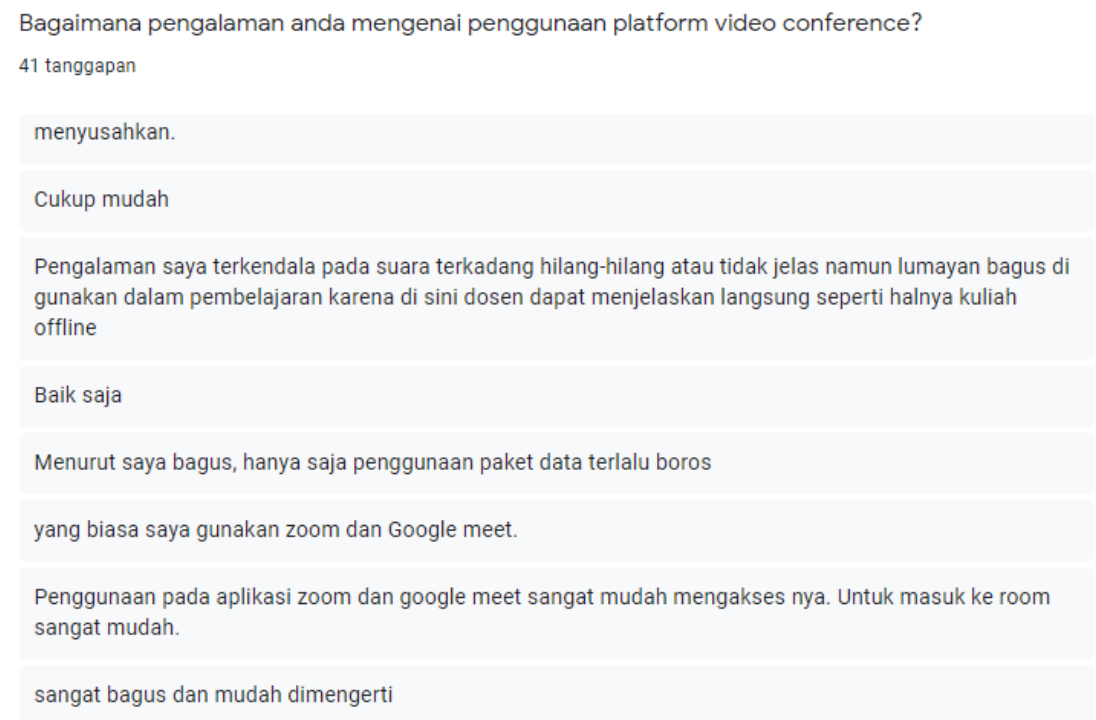

Gambar 5. Persepsi platform video conference

Pembelajaran daring menggunakan platform video conference membuat pembelajaran online efektif layaknya tatap muka namun mahasiswa terkendala jaringan jika pengaktifan video. Ditambahkan pula oleh Iswandari (2020) bahwa pelmbelajaran online berbantuan zoom meeting dapat meningkatkan hasil belajar dari $76 \%$ pada siklus pertama, $88 \%$ pada siklus kedua, menjadi $94 \%$ pada siklus ketiga dengan penerapan model project based learning.

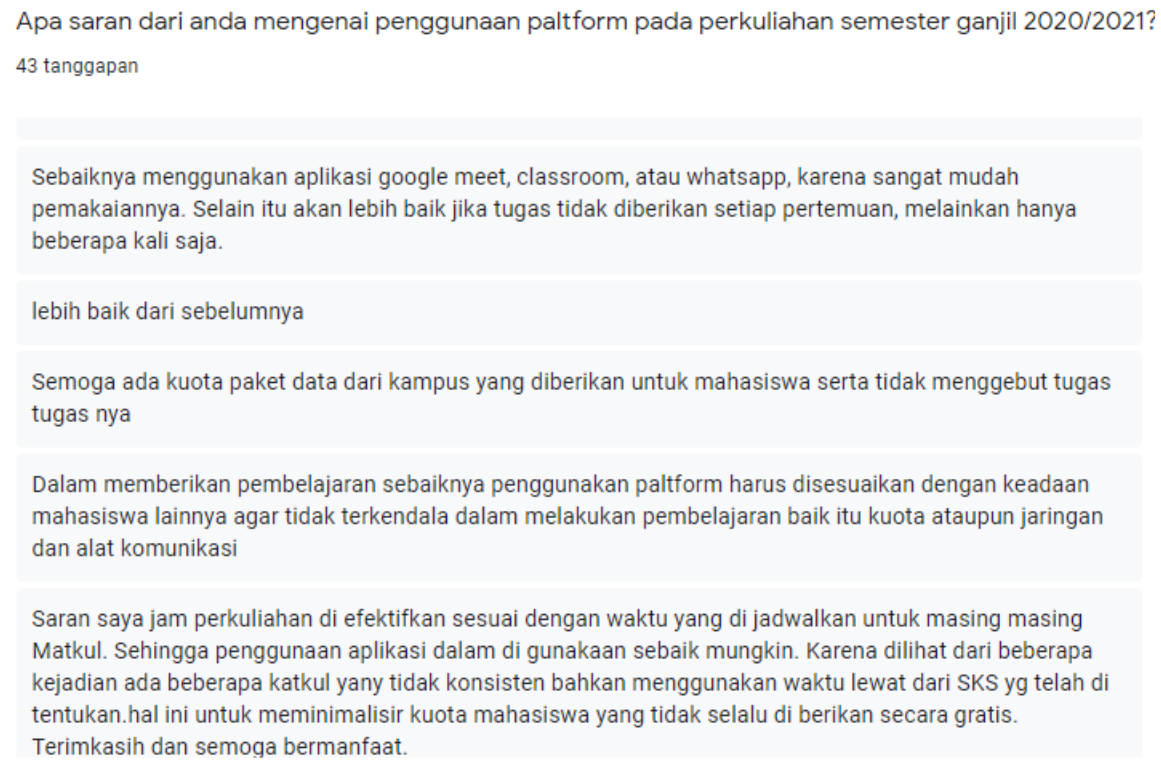

\section{Gambar 6. Pembelajaran daring}


Deskripsi dari hasil persepsi mahasiswa pada hasil angket terdapat beberapa tanggapan mengenai kemampuan mahasiswa terhadap bebagai platform yang digunakan dalam pembelajaran daring berupa, mahasiswa masih antusias menyuarakan untuk kegiatan pembelajaran secara tatap muka, penggunaan platform sebaiknya fitur yang familiar dan mudah dalam pengaplikasiannya, sebaiknya ada waktu di mana mengkonsep blended learning atau satu pertemuan bertatap muka agar penyampaian pembelajaran berjalan efektif dan efisien, bagi dosen lebih kreatif lagi dalam pemanfaatan pembelajaran daring, pemberian tugas pada pembelajaran daring tidak harus setiap pertemuan, keterlambatan pengiriman tugas dan absensi pada pembelajaran daring dikarenakan akses internet di daerah tempat tinggal mahasiswa berbeda-beda, banyak materi yang tidak dipahami jika online, penggunaan platform bervariasi dan sebaiknya hemat kuota misal berupa video materi pembelajaran singkat kirim via whatsapp dan tugas dikirim melalui classroom, sebaiknya materi diberikan sesuai jam matakuliah yang sudah ditetapkan, penggunaan platform yang mudah di akses seperti whatsapp agar respon lebih baik. Saifuddin (2017) juga berpendapat bahwa mahasiswa mengetahui e-learning atau pembelajaran daring 86,3 \% dalam mendukung pembelajaran secara online, $77 \%$ menyatakan puas dengan pembelajaran secara daring. Juga didapatkan pengalaman baru dalam kesiapan abad 21, meningkatkan motivasi, memahami materi yang dapat di baca berulang-ulang, hingga kesiapan fasilitas dalam pembelajaran daring.

\section{SIMPULAN}

Hasil penelitian ini dapat memberikan gambaran untuk dosen dapat lebih kreatif dalam memanajemen pembelajaran daring, mengidentifikasi keadaan mahasiswa, pemilihan platform yang sesuai, dan aktif merespon komunikasi dari mahasiswa.untuk mahasiswa menyiapkan waktu khusus perkuliahan, selalu mengecek paket internet, trading pemanfaatan penggunaan platform yang bervariasi. Hasil temuan yang peneliti dapatkan menjadi pegangan untuk perkuliahan daring bahwa penggunaan platform dapat disesuaikan dengan kondisi mahasiswa dalam kesiapan pemanfaatan fitur terkhusus kesiapan sarana dan prasarana yang dimiliki.

\section{REFERENSI}

Adijaya.N. dan Santoso.L.P.2018. persepsi mahasiswa dalam pembelajaran online. Wanastra. 10(2), 55-60.

Alfina, O. (2020). Penerapan Lms-Google Classroom Dalam Pembelajaran Daring Selama Pandemi Covid-19. MAJALAH ILMIAH METHODA, 10(1), 38-46.

Creswell.J.W. 2012. educational research: planning, conducing, dan evaluating quantitative and qualitative research. Educational research. Vol (4).

Dewi, W. A. F. (2020). Dampak Covid-19 terhadap implementasi pembelajaran daring di Sekolah Dasar. Edukatif: Jurnal Ilmu Pendidikan, 2(1), 55-61.

Fallows.D. 2004 the internet and daily life. Pew research center's internet and american life project.

Fenturini, A. (2020). PENGEMBANGAN MEDIA PEMBELAJARAN MELALUI METODE UP-CYCLING DALAM PEMBELAJARAN TEMATIK SUB TEMA KOMPONEN EKOSISTEM PADA KELAS 5 SD (Doctoral dissertation, Universitas Muhammadiyah Malang).

Ferdiana, S. (2020). Persepsi Mahasiswa tentang Penggunaan Media Daring pada Program Studi S1 Ilmu Gizi Sekolah Tinggi Ilmu Kesehatan Surabaya selama 
Masa Pandemi Corona Virus Disease (COVID-19). Indonesian Journal of Science Learning, $\quad l(1 \quad$ SE-Articles). http://jurnalftk.uinsby.ac.id/index.php/IJSL/article/view/631.

Fitriyani, Y., Fauzi, I., \& Sari, M. Z. (2020). Motivasi Belajar Mahasiswa Pada Pembelajaran Daring Selama Pandemik Covid-19. Jurnal Kependidikan: Jurnal Hasil Penelitian dan Kajian Kepustakaan di Bidang Pendidikan, Pengajaran dan Pembelajaran, 6(2), 165-175.

Fortune.M.F., Spielmen.M., and Pangelinan.D.T. 2011. student's perceptionsof online or face to face learning and social media in hospitality, recreation and tourism. MERLOT of journal online learning and teaching. 7(1). 1-16.

Gifan, A., Ramadani, N., \& Suryani, E. (2020). PAKEM the Box of Pinisi sebagai Reaktualisasi Pembelajaran pada Siswa Sekolah Dasar. Indonesian Journal of Social and Educational Studies, 1(1).

Hadi, L. (2020). PERSEPSI MAHASISWA TERHADAP PEMBELAJARAN DARING DI MASA PANDEMIK COVID-19. Jurnal Zarah, 8(2), 56-61.

Handarini, O. I., \& Wulandari, S. S. (2020). Pembelajaran Daring Sebagai Upaya Study From Home (SFH) Selama Pandemi Covid 19. Jurnal Pendidikan Administrasi Perkantoran (JPAP), 8(3), 496-503.

Hapsari, S. A., \& Pamungkas, H. (2019). Pemanfaatan google classroom sebagai media pembelajaran online di universitas dian nuswantoro. WACANA: Jurnal Ilmiah Ilmu Komunikasi, 18(2), 225-233.

Hartati, W. (2020). Persepsi mahasiswa tentang penerapan e-learning pada masa darurat covid-19. APOTEMA: Jurnal Program Studi Pendidikan Matematika, 6(2), 158159.

Iswandari, Y. Peningkatan Hasil Belajar Pembelajaran Daring Melalui Model Project Based Learning Berbantu Platform Zoom Meeting. In Social, Humanities, and Educational Studies (SHEs): Conference Series (Vol. 3, No. 3, pp. 187-194).

Julkifli, J., Masrukhi, M., \& Susilaningsih, E. (2020). Learning Strategy of Pancasila and Citizenship Education on Students' Character Development. Journal of Primary Education, 9(1), 14-21.

Krismony, N. P. A., Parmiti, D. P., \& Japa, I. G. N. (2020). PENGEMBANGAN INSTRUMEN PENILAIAN UNTUK MENGUKUR MOTIVASI BELAJAR IPA SISWA SD KELAS V. Jurnal Ilmiah Pendidikan Profesi Guru, 3(2).

Lin. E., and Lin.C.H. 2015. the effect of teacher student's interaction on student's learning achievement and online tutoring environment. International journal of technical research and apllications E-ISSN:2320-8163. 22(22). 19-22.

Maresta, N., \& Abdurrahman, A. (2020). NILAI-NILAI PENDIDIKAN KARAKTER DALAM KABA SABAI NAN ALUIH KARYA M. RASYID MANGGIS DT. RAJO PENGHULU DAN IMPLIKASINYA DALAM PEMBELAJARAN TEKS HIKAYAT KELAS X SMA. Pendidikan Bahasa Indonesia, 8(5), 280289.

Maudiarti, S. (2018). Penerapan E-Learning di Perguruan Tinggi. PERSPEKTIF Ilmu Pendidikan, 32(1), 51-66.

Nahdi, D. S., \& Jatisunda, M. G. (2020). Analisis literasi digital calon guru SD dalam pembelajaran berbasis virtual classroom di masa pandemi covid-19. Jurnal Cakrawala Pendas, 6(2). 
Rahmawati, R., \& Putri, E. M. I. (2020, June). Learning From Home dalam Perspektif Persepsi Mahasiswa Era Pandemi Covid-19. In Prosiding Seminar Nasional Hardiknas (Vol. 1, pp. 17-24).

Rahmatih, A. N., \& Fauzi, A. (2020). Persepsi Mahasiswa Calon Guru Sekolah Dasar dalam Menanggapi Perkuliahan secara Daring Selama Masa Covid19. MODELING: Jurnal Program Studi PGMI, 7(2), 143-153.

Rustaman, A. H. (2020). Efektivitas penggunaan aplikasi daring, video conference dan sosial media pada mata kuliah komputer grafis 1 di masa pandemi covid-19. JISIP (Jurnal Ilmu Sosial dan Pendidikan), 4(3).

Sadikin, A., \& Hamidah, A. (2020). Pembelajaran Daring di Tengah Wabah Covid19:(Online Learning in the Middle of the Covid-19 Pandemic). Biodik, 6(2), 214224.

Saifuddin. M.F. 2017. e-learning dalam persepsi mahasiswa. Varia pendidikan. Vol 29, No 2. desember 2017: 102-109.

Trisnadewi, K., \& Muliani, N. M. (2020). Pembelajaran Daring di Masa Pandemi Covid19. COVID-19: Perspektif Pendidikan, 35.

Zhafira, N. H., Ertika, Y., \& Chairiyaton, C. (2020). Persepsi Mahasiswa Terhadap Perkuliahan Daring Sebagai Sarana Pembelajaran. Jurnal Bisnis Dan Kajian Strategi Manajemen, 4(1). 